\title{
POULTRY PRODUCTION AND SELLING CLASSIFICATIONS IN JIMMA HORRO WEREDA, OROMIA WESTERN WOLLEGA
}

\author{
Soresa Shuma Abdisa ${ }^{1} ه$, Abdisa Abraham Challa ${ }^{2}$, Moti Erena Bedane ${ }^{3}$ \\ ${ }^{1}$ Department of Animal Science, College of Agriculture Veterinary Medicine Dambi Dollo University, Ethiopia. \\ ${ }^{2}$ Department of Natural resource management, College of Agriculture Veterinary Medicine Dambi Dollo \\ University, Ethiopia. \\ ${ }^{3}$ Department of Agricultural Economics, College of Agriculture Veterinary Medicine Dambi Dollo University, \\ Ethiopia.
}

Received 2 September 2021

Accepted 16 September 2021

Published 30 September2021

\section{CorrespondingAuthor}

Soresa Shuma Abdisa, soriyeshuma@gmail.com

DOI

10.29121/granthaalayah.v9.i9.2021. 4237

Funding: This research received no specific grant from any funding agency in the public, commercial, or not-for-profit sectors.

Copyright: (C) 2021 The Author(s). This is an open access article distributed under the terms of the Creative Commons Attribution License, which permits unrestricted use, distribution, and reproduction in any medium, provided the original author and source are credited.

\section{ABSTRACT}

A survey was conducted at Jimma Horro District, Oromia Region. The key objective of the study was to describe the present poultry production and selling structure of the Jimma Horro District. Over-all 165 aimlessly nominated poultry holders were used for the study. As the results, indicate there were three poultry manufacture structures in the study areas, foraging with seasonal feed supplementation (86.7\%). The mean amount of eggs placed and yearly yield of local hens was 12.3 and 39.8eggs respectively. There was no formal chicken and chicken product marketing channel in the Jimma Horro District and informal marketing of live birds and eggs involving open markets are common throughout the district.

Keywords: Community, Manufacture, Native, Searching

\section{INTRODUCTION}

Diverse survey illustration that likewise to additional African countries, community level fowl production pays to several income results in Ethiopia, counting sex equivalence, revenue producing, as well as its role in traditional, spiritual and old-style practices Tadelle et al. (2003b), Bush, 2006; FAO, 2009). In Ethiopia fowl are general and virtually all pastoral household possesses chicken Tadelle et al. (2003a). The chicken public in Ethiopian is assessed to be around 56.87 million (CSA, 2015). About $97.82 \%$ of the fowl production in Ethiopia is by tradition managed (FAO, 2009). In the pastoral areas of Ethiopia, greatest of the household have no isolated house for their chickens and the chickens living organized by means of the human common people within one house. In link to this, the household have no intentional nourishing of their chickens and scavenging is almost the merely basis of feedstuff and they have no prearranged upbringing Solomon (2007) Mengesha et al., 2011).

Indigenous chicken receipts the advanced out of a hundred in the country $(95.86 \%)$ as well as in the study part of north western Tigray (95.6\%) in relations of populace (CSA, 2015). Though, the productivity (egg and meat) is little, have minor body size, little hatchability at around 70\%, great death expected at around $40-60 \%$ of chicks die throughout their first eight weeks of age mostly due to illness and killers as associated to exotic chicken Solomon (2007)

To advance the fowl production, numerous exotic chicken types have been distributed to the household over the last 50 years in the country 
Solomon (2007) and in the assessed parts the chicken was circulated for the last 15 years (Tselemti and Tahtay Koraro Bureau of livestock and Pastoral Growth, 2016). Then the implementation of these exotic chicken type in maximum portions of the country is not capable due to its limitation by a usual of issues counting sub-optimal managing, absence of additional feedstuff, little hereditary possible and great death amount due to illnesses and killers Tadelle et al. (2003b), Tekelewold et al., 2006). In the assessed area there is no any recognized study directing to the chicken controlling and the awareness of farmers on exotic chicken type. Hence, the goal of this survey was to evaluate chicken production situation and to measure the selling system of chicken in the study Woredas.

\section{MATERIALS AND METHODS 2.1. DESCRIPTION OF STUDY AREAS}

The survey was conducted in Jima Horro District of KellemWollega Zone. Jimma Horro district is located at $641 \mathrm{kmWest}$ of Addis Ababa. The altitude of the district ranges between 1400 and 1800 meters above sea level, with average annual minimum and maximum temperature of $18{ }^{\circ} \mathrm{C}$, and $27^{\circ} \mathrm{C}$, respectively whereas the yearly rain ranges from 700 to $1000 \mathrm{~mm}$ (Ethiopian Digital Elevation Model, 2019). In the survey area agriculture is the major economic activity of the district. The livestock resource of the study district comprises of 66267 cattle, 19421 sheep, 13647 goats, 257 horses, 6809 mules, 9873 donkeys, and 68401chickens (Jimma Horo Livestock office 2018). The total human population of the district is about 56403 , of which $50 \%$ is reported to be male (Ethiopian Digital Elevation Model 2019).

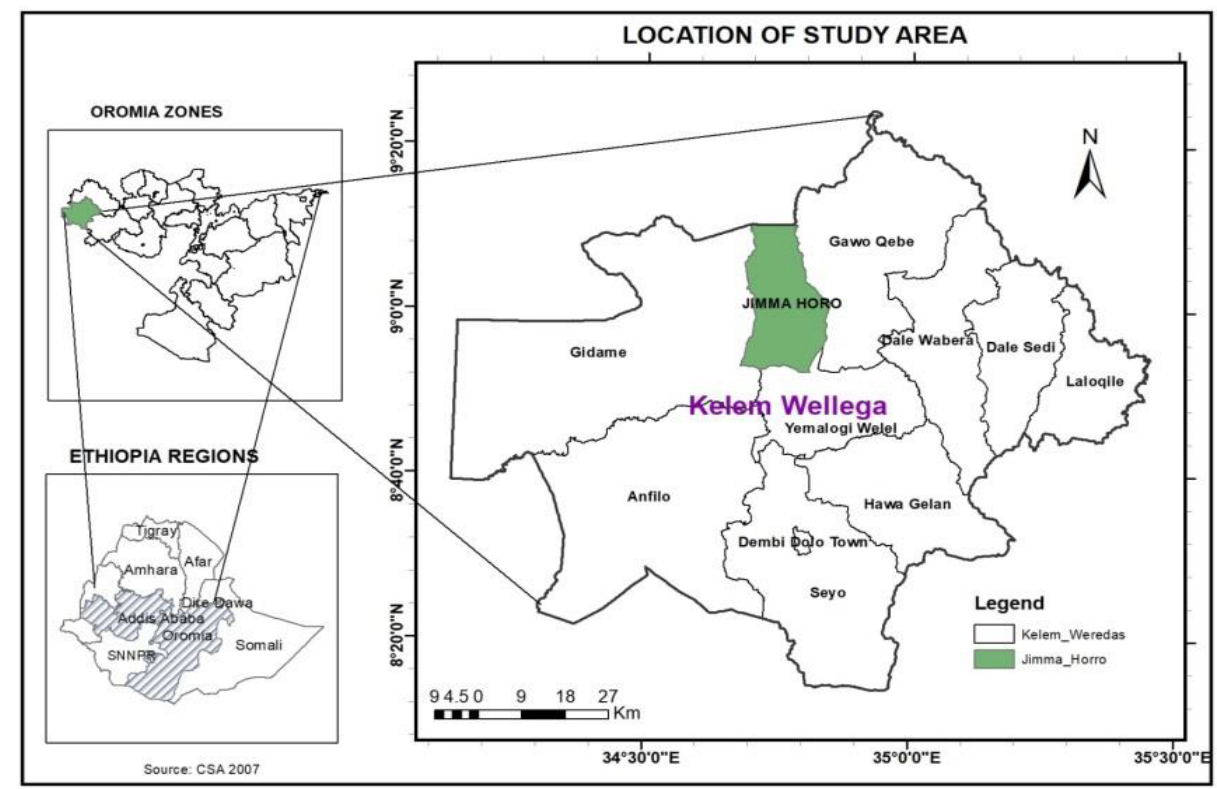

Figure 1 Map of Jimma Horro Horo District (Study areas).

\subsection{SELECTION OF THE STUDY AREAS AND METHOD OF DATA COLLECTION \\ 2.2.1. SELECTION OF THE STUDY AREAS}

The three Kebeles Nunu (lowland), Ilu kitaye (mid altitude) and Tibe (highland) were purposively selected based on the representativeness, accessibility and availability of exotic and indigenous chicken ecotypes. 


\subsubsection{HOUSEHOLDS SAMPLING TECHNIQUES}

A rapid informal field survey and discussion with the district livestock and fishery office experts were made to know accessibility and availability of exotic and indigenous chicken ecotypes in study areas. After further discussion with the district agricultural development agents and key informants, a total of 9 kebeles (3from Tibe, 3from Ilu Kitaye and 3fromNunu) were selected and discussion was conducted with them.

After all the chicken owners of the selected Kebeles were listed during the reconnaissance study then the total numbers of the households to be interviewed were estimated according to Yamane (1967) with 92\% confidence level. After knowing the total number of farmer's selection was done randomly.

$$
\begin{aligned}
& \mathrm{n}=\mathrm{N} / 1+\mathrm{N}(\mathrm{e}) 2 . \\
& \quad \text { Where; } \mathrm{n}=\text { sample size } \\
& \mathrm{N}=\text { total number of households } \\
& 1=\text { probability the event occurring } \\
& \mathrm{e}=\text { maximum variability or margin of error }=8(0.08)
\end{aligned}
$$

\subsubsection{DATA COLLECTION Primary Data Source}

Data was generated by administrating a structured questionnaire, employing field measurements, organizing group discussion and from secondary sources. Basically, the study was composed of Chicken production and Marketing System.

The questionnaire was translated in to Afaan Oromo. It was pre-tested before administration and some re-arrangement and correction was made in accordance with respondents' perception. Information's gathered through questionnaires were: socio economic characteristics of the respondents like sex, age, education level, household size, livestock possession, socio economic benefit of chicken production and major production of egg and meat, reproductive performances like age at first egg, purpose of keeping chicken, feed and feeding situations, like major feed sources, supplementation, water source; in the areas.

Information was collected from individual farmers, extension officers, key informants and village group using both indigenous and exotic production. The exercises were aimed at assessing the perspectives of the chicken management system including intra household dynamics (division of labor, access to and control over of resources and decision making on resources), Information on indigenous and exotic breeds of chicken including; flock characteristics and ownership, and flock performance, use pattern, off take and loss of chicken and all aspects of chicken managements were collected.

Secondary sources: secondary records were calm from district livestock and fishery resource office and the respective kebele offices of livestock and fishery resource to complement the distribution, number of chickens across the different kebeles and management system.

Finally, closer visits in and around the residential quarters of the villages were made in order to obtain first hand observation on different aspects of chicken management from individual households and to involve women in the households since their participation in the village meetings and other data collection activities is expected to be rather restricted. 


\subsection{STATISTICAL ANALYSIS}

Data collected through questionnaire, observation, and interviews were analyzed by descriptive statistics using Statistical Package for Social Sciences (SPSS) version 20 .

\section{RESULTS AND DISCUSSION}

Family characteristics the middling household size in the survey Wereda existed $5.9 \pm$ (2.146). The mean household size branded in the survey part was advanced than the countrywide middling of 5.2 persons (CACC, 2003) and the designated 5.4 for North Western Amhara Area (Halima, 2007). The middling land farm per family in the weredas was $2 \pm 0.2$ hectares.

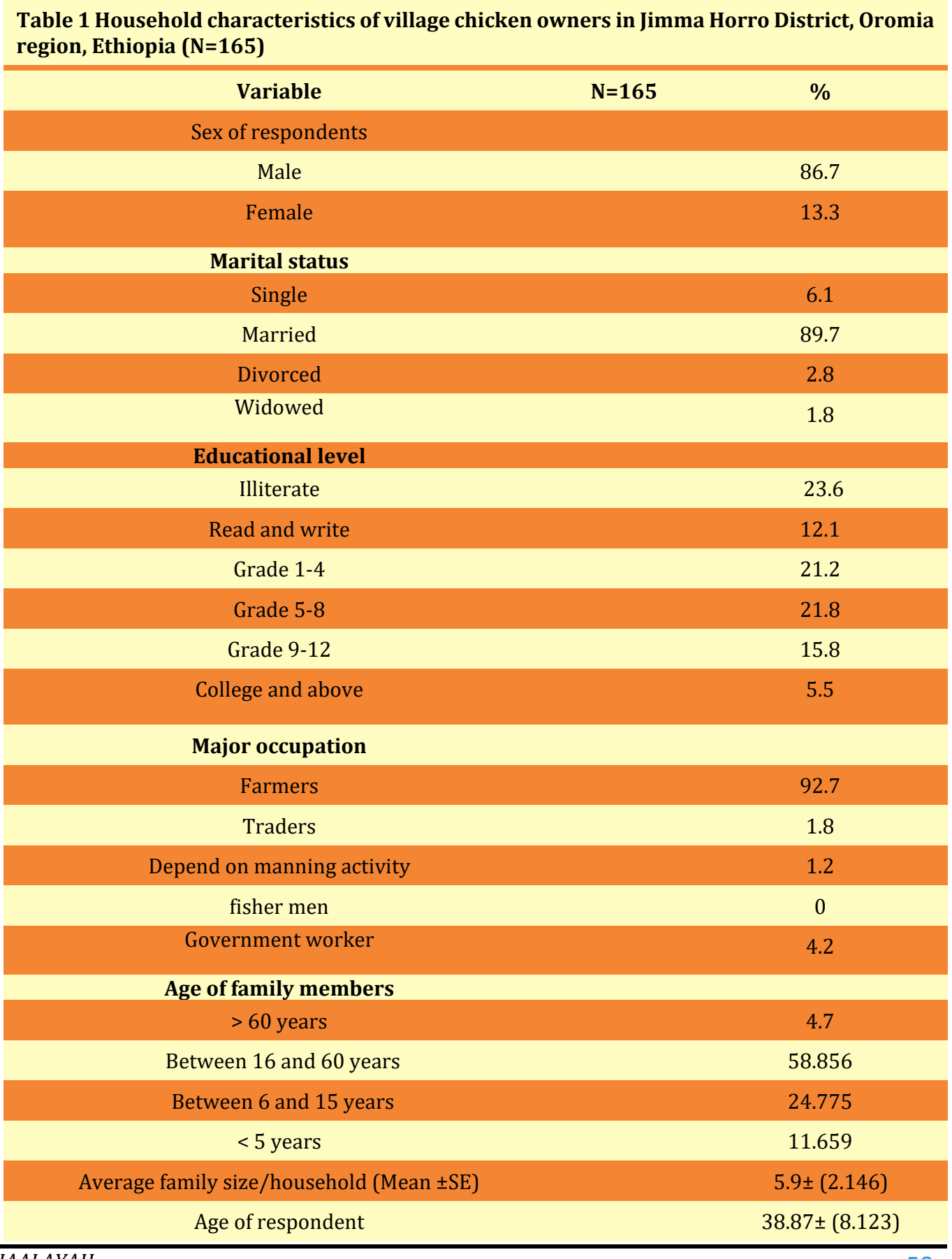




\section{Chicken Production system and flock size:}

The maximum leading (86.7\%) chicken production system well-known in the in Jimma Horro weredas was extensive through systematic feedstuff addition. Likewise, Halima (2007) stated the greatest main (99.2\%) poultry production classification in Northwest Amhara stayed extensive type with only periodic feed supplementation. The mean flock size/household was $15.78 \pm 1.9$ birds (Table 2). The outcome showed that the middling flock size of the area was greater than the outcomes gained (13.7 fowl/family) in other designated areas of Northwest Amhara Fisseha et al. (2014). The outcome stayed in link with the results of Gueye (1997) who described 5-20 fowls/family in greatest African nations. However, a moderately greater chicken herd size/family (19 birds), through a hen to cock ratio of 4.4:1, was described by Khalafalla et al. (2001) in Sudan.

\begin{tabular}{|c|c|c|c|c|c|c|c|}
\hline & Cock & Hen & Pullate & Cockerels & Chicks & Over all & \\
\hline & Mean \pm SE & Mean \pm SE & Mean \pm SE & Mean \pm SE & Mean \pm SE & & Range \\
\hline Tibe & $2.9 \pm 0.58$ & $4.05 \pm 0.7$ & $3.29 \pm 0.8$ & $2.95 \pm 0.9$ & $4.35 \pm 0.5$ & $15.78 \pm 1.8$ & $3-105$ \\
\hline $\begin{array}{c}\text { Ilu } \\
\text { Kitaye }\end{array}$ & $2.04 \pm 0.1$ & $3.40 \pm 0.3$ & $2.33 \pm 0.3$ & $1.75 \pm 0.2$ & $2.69 \pm 0.3$ & $13.75 \pm 1.4$ & Feb- 60 \\
\hline Nunu & $0.93 \pm 0.4$ & $3.16 \pm 0.2$ & $0.49 \pm 0.1$ & $0.38 \pm 0.1$ & $1.38 \pm 0.4$ & $6.6 \pm 0.7$ & 20-Feb \\
\hline $\begin{array}{l}\text { Grand } \\
\text { mean }\end{array}$ & $1.96 \pm 0.3$ & $3.54 \pm 0.3$ & $2.04 \pm 0.3$ & $1.69 \pm 0.3$ & $2.81 \pm 0.2$ & $12.04 \pm 0.9$ & $2-105$ \\
\hline
\end{tabular}

\section{Marketing systems \\ Characteristics of markets:}

There was no formal chicken and chicken product marketing channel in the Jimma Horro District and informal marketing of live birds and eggs involving open markets are common throughout the district. The farmers directly sell their chicken to consumers and/or to small retail traders who take them to large urban centers. Live chickens and eggs are sold either at the farm gate, small village market (primary market) or at larger district market (Secondary market in the town). There is exchange of commodities throughout the week with one regular market day at the center of each Kebeles.

Marketing limitations: The product of the present study showed that spiritual holydays were extremely related with eating chicken meat and eggs. Seasonality in amounts of chicken harvests was the main (90.6\%) chicken and egg selling limitation of the survey parts. Additional promotion limitations known in the parts involved: little source of chicken harvests, absence of market passages, lack of suitable marketing information, shortage of chicken passage and egg management services, absence of credits and wealth to expand chicken manufacture and selling actions.

\section{CONCLUSION}

The outcome of current survey showed extensive with regular feedstuff addition stayed the main poultry manufacture classification form occurred at Jimma Horro District, Oromia Region. Endorsement The study outcome designated that regulator of sicknesses, mostly Newcastle disease, was create actual serious in the survey part. It might be realized concluded development in veterinary and optional facilities. Delivery of suitable exercises to chicken manufacturers of fresh farming 
performs might be significant to recover the awareness of community poultry manufacturers. Delivery of suitable selling evidence to community poultry makers might be significant for development of poultry and egg selling structure of the survey part.

\section{REFERENCES}

Ethiopia Economic Association (EEA) (2002). Land tenure and agricultural development in Ethiopia. Ethiopia Economic policy Research Institute, Addis Ababa.

Fisseha M, Mohammed N and Getenet Z (2014). Characterization of village chicken production and marketing systems in selected districts of North Western Amhara, Ethiopia. African Journal of Agricultural Research. 9(41): 30913097. Retrieved from https://doi.org/10.5897/AJAR2014.8920

Greece, 2:17-26. Central Agricultural Census Commission (CACC) (2003). Ethiopian Agricultural Sample Enumeration, 2001/2002. Statistical report on farm management practices, livestock and farm implements part II, Addis Ababa, Ethiopia. 233p.

Guagusa Sh (2002). District office of Agriculture and Rural Development annual report. 2002 budget year.

Gueye EF (1998). Village egg and fowl meat production in Africa. WPSA Journal, 54: 73-86. Retrieved from https://doi.org/10.1079/WPS19980007

Gueye EF (2000). Women and poultry production in Africa. Development in Practice, 10: 98-102. $\quad$ Retrieved from https://doi.org/10.1080/09614520052565

Hassen Mogesse H (2007). Phenotypic and genetic characterization of indigenous chicken populations in North-West Ethiopia. PhD Thesis. Submitted to the faculty of natural and agricultural sciences department of animal, wildlife and grassland Sciences. University of the Free State, Bloemfontein, South Africa. Retrieved from http://hdl.handle.net/11660/2207

Kassambara AI (1989). La production avicole au Mali: problems et perspectives. In : Proceeding of International workshop on rural poultry in Africa, 13-16 November 1989, IIe-Ife, Nigeria. pp: 140-150.

Katule AM (1992). Study on the potential value of indigenous chickens in Tanzania. Rural Poultry Development Newsletter. pp 2:4.

Khalafalla AI, Awad S and Hass W (2001). Village poultry production in the Sudan. Department of Microbiology, Faculty of Veterinary Science, University of Khartoum, Khartoum North, Sudan. Department of Microbiology, Faculty of Veterinary Science, University of Khartoum, Khartoum North, Sudan. Retrieved from http://www-naweb.iaea.org/nafa/Aph/public/9-villagekhalafalla.pdf

Mecha (2002). District office of Agriculture and Rural Development annual report. 2002 EC year.

Serkalem T, Hagos A and Zeleke A (2005). Sero-prevalence study of Newcastle disease in local chickens in central Ethiopia. Inter. Journal of applied veterinary medicine. Retrieved from http://jarvm.com/articles/Vol3Iss1/TADESSEIJARVMVol3No1web.pdf

Solomon Demeke. (2007). Suitability of hay-box brooding technology to rural household poultry production system. Jimma University College of Agriculture and Veterinary Medicine, Jimma, Ethiopia. Retrieved from https://lrrd.cipav.org.co/lrrd19/1/deme19003.htm 
Statistical Packages for Social Sciences (SPSS) (2002). SPSS version 12. SPSS Inc. Chicago, Illinois.

Tadelle D and Ogle B (1996). Studies on poultry production systems in the central highlands of Ethiopia. M.Sc Thesis. Swedish University of Agricultural Sciences. 72 p. Retrieved from https://agris.fao.org/agrissearch/search.do?recordID=SE9710408

Tadelle D, Million T, Alemu Y and Peters KJ (2003). Village chicken production systems in Ethiopia: Use patterns and performance valuation and chicken products and socio-economic functions of chicken. Livestock Research for Rural Development, 15. (1) 2003. Retrieved from http://www.Irrd.org/lrrd15/1/tadea151.htm

Wilson RT (1979). Production of poultry in Darfur, Sudan, under simulated traditional conditions. Tropical Animal Health and Production journal, 11: 143-150. https://doi.org/10.1007/BF02237790 